\title{
An Analysis of Cultural Alienation and Trauma in Neel Mukherjee's A Life Apart
}

M. Maria Juliet Rani

M.Phil Scholar

Sadakathullah Appa College (Autonomous)

Tirunelveli, Tamil Nadu, India

mariajulietrani@gmail.com

Dr. A. Alis Sofia

M.A., M.Phil., Ph.D.

Assistant Professor and Research Guide

Research Department of English

Sadakathullah Appa College (Autonomous)

Tirunelveli, Tamil Nadu, India

Abstract

The significant role of Trauma theory in literature lights the psyche of an individual precisely. The twenty first century paves the gateway to contemplate the struggles and the conflicts of inner self. Sigmund Freud is the pioneer to set forth the psycho-analytical theory in distinctive aspects in the late twentieth century. He is the root for all other contemporary writers to follow suit. Neel Mukherjee is one of the foremost novelists in English literature, who depicts the protagonist's distress in an alienated land. Memories play a vital role in which the protagonist connects the past memories with that of the present. The protagonist 
finds the way to escape from his bitter life by becoming a homosexual. This paper aims to project the traumatic condition of the protagonist in Neel Mukherjee's A Life Apart.

Keywords: Psychological upheaval, Trauma, Alienation, Predicament, Distress, Escapism.

A Life Apart is Neel Mukherjee's debut novel. It describes about a young man,

Ritwik Ghosh. He is the protagonist of this fiction. The novel is set in the1990s. It begins with his parents' funeral in Calcutta, India. Ritwik moves to England at the age of twenty one. He has recently got the scholarship from Oxford for his higher studies. Neel Mukherjee is a contemporary Indian writer. He is the author of critically renowned novels such as Past Continuous or A Life Apart (2008), The Lives of others (2008) which was shortlisted for the Man Booker Prize and A State of Freedom (2017). Most of his novels are discussed the misery and the conflicts of contemporary India.

As Ritwik begins his new life in England, his past memories are continued in his present life. Thus, the novel subtitles as Past Continuous. The novel is told in the third person narration. Every event in England is connected with Ritwik's past life in India. Throughout the novel, he is frequently cornered with the hands of cultural alienation. As he arrives in England, he has innumerable dreams about his new life. But later, he comes to realize the fact that, though he gets the opportunity to do his degree in Oxford, he is seen as an outsider in the eyes of western people.

Gradually, Ritwik recognises his position in an alien land. Everyone in the college feels disgusted on him due to his skin complexion and his worse pronunciation in English language. Ritwik is unable to keep the unexpected events that agitate him a lot. However, he discovers himself aloof from the new sphere. A typical life in new province separates him from his huge surmise. Ritwik's observation on these issues causes the extreme cold in his subconscious mind. It affects his routine life. On the other hand, against his will, his psyche slowly engages with the evil personality. 
Generally, the psychological trauma displays the inner world of a man. It disturbs and overwhelms one's ability. It diminishes the sense of a single character. Consequently, it leads a complex ending of oneself. The pain and the wound are deeply coloured by foreshadowing memories, awful remembrance, introspection and flashback in the novel. Being a living author in the current era, Mukherjee has an aim to represent the distress and the outcome of immigrants in an appropriate manner. Mukherjee takes data approximately about current themes such as cultural trauma, cultural displacement and its cultural dynamics.

Literature and psycho-analysis are interconnected by analysing the human psyche. It depicts the characters who are representing in real life. In other words, trauma refers to a state of distressed mind. It damages and devastates the human being's mental balances. Cultural trauma has an inseparably ethical, historical and political dimension. Therefore, the writer cannot limit in particular field of psychological studies. It includes feelings and emotions. Besides, it employs the serious consequences; particularly it pictures Ritwik's memories and its impacts in the new region. The sort of insecurity is the reason for one's psychological difficulties.

The protagonist encounters the typical nuances that enrol him to recollect such things like sexual abuse, domestic violence and discrimination. Ritwik is frequently experienced the domestic violence at the age of six. His mother has abused him for trivial reasons. The abnormality of his mind pursues him to do things against moralistic values. The path of adversity and misery would definitely lead to a path of wisdom. However, on the contrast, he selects the path of living a life that is not welcomed by many.

Mukherjee believes that the immigrants are identified as subordinate in the eyes of west. Ritwik's family was a joint family once. His mother had the immense responsibility to take care of the entire family. She was troubling to solve the financial problem between herself and her husband. So they used to quarrel with each other. Therefore, she used to beat 
her sons often, particularly Ritwik. This showcases the Indian family's setup and its problematic life. The Indian families are comprehensively attached with the emotional ties. The families are meant for the subtle of providers and the receivers. But in contrary, Ritwik's family was subsequently troublesome. The burden of responsibility collapsed the relationship. Ritwik was unhappy and quite anxious, when his parents fought with each other. From a very young age he was grown up with the sense of anger through his parents. According to Ritwik twenty five is the right time for facing with the big incidents like death, responsibility and so on. But ironically, his parents are died when he is at the age of twenty one.

Ritwik never forgets his first day in England, when he has carried two heavy suitcases. The room is too small to keep all his belongings. He could hardly move around the room. The heavy rain is so typical to him, because the weather condition does neither resemble the monsoon of Calcutta nor any other place he longs for. He feels a sense of inbetween status while residing in the room. In England, he has a chance to encounter the infinite hints of drizzle. Unlike India, England is extremely cold. This causes him to feel a texture of unpleasant moments. On the other hand, Ritwik recollects this idealised monsoon, which has been described once in his school text books. But now he encounters these directly. In the rainy days, he frequently textures the nostalgia of his home land; despite he resists to reminiscing his life in Calcutta.

On rainy days like this, nostalgia wraps around him like an insidious Fog; it is everywhere, but while inside it, he can hardly tell how enveloped he is in it. Nostalgia, and something else. He won't name it, he won't even think about it because if he lets go for even a few seconds, the grey, sour rain outside will bend him to its own form. $(39,40)$ 
As Ritwik studies in Oxford, he confronts the discrimination in many ways. His skin colour engenders the westerners to stay far away from him. He is extremely outraged by these prejudices. It is as follows,

Ritwik also realizes, in slow stages, that his is a type of minority appeal, catering to the 'special interest' group rather than the mainstream, because of his nationality, looks, skin colour. He keeps pushing the word 'race' away. The mainstream is blonde, white, young, slim. Or more accurately that is the desired mainstream. (124)

The typical weather condition has brought out dandruff in Ritwik's hair. For the first time he buys things for trivial reasons. There is a body shop where he gets lip balm, Antidandruff shampoo like this. These products decrease the impact of weather conditions in his body. Sarah is Ritwik's classmate and his friend in Oxford. She is a part time employee with an organization named The National Society for the Prevention of Cruelty to Children. It is a kind of a charity trust. It prevents the children from the child labours, domestic abuses, physical sexual abuses and parental violence. As Sarah shares about the child exploitation, Ritwik recollects his bitter past experiences in his mother country. Mukherjee emphasizes the necessity of children care through the character Sarah. He describes about child labours who are working as tea- shack boys, domestic servants in the many places in England. The poor underage teenagers are working nearly twelve hours to sixteen hours for frugal meals. Many times these children are beaten up for breaking glass involuntarily. The poor and innocent children in the world are encountering merciless workloads and the stress at the age of below ten. Mukherjee is a writer and much more a revolutionary one, who respects the children's law. Hence he stresses the rights of children. As stated by the survey of children care, the crimes such as child labours, parental abuse and sexual abuse never get reported explicitly, because the children are unable to express their silent encounters. 
According to the western mind, the word 'India' brings up the picture of poverty. Because they know that Indian country is ultimately represented the class divisions and the democratic politics. Though India is technologically and scientifically improved, it has the big economic degradations that consequences the poverty in India. As per Ritwik's view on India, those who are rich, they are highly privileged and those who are not rich they are less privileged. Obviously, the privileged one is in fact the lucky because he or she can get the good education by the biased society. Subsequently, the less privileged people are not given any constitutional rights in actual life.

Ritwik was raised from the lower background. His family struggled to get a daily wage for their survival. His family was entirely depended on his father's wage. Ritwik was inspired by his father. His father was not educated well, yet his father was aware of the significant role of English. So he used to buy many English books to Ritwik. His father used to say "without knowledge of the English language, you're crippled." (110)

Ritwik is a typical Indian boy who longs for his mother's love as every child wants. But he could not get the love that leads him to escape from the custody of his family. In his teenage years, he has forced to think about his mother's death due to her extreme brutality over him. Even at the age of six, he has got severe assault from his mother for minor errors. But his mother's sudden death causes neither glad nor sorrow to him. Ritwik is one of the victims of social discrimination in England. These incidents are the root for his future problematic life. He sees everything so complicatedly. Moreover, he has grown up in a household where his uncles were the most awful models for any child, because their uncles were drunkards, gamblers and smokers.

The universal ideology manipulates every marginal people unfavourably. The words such as marginal, peripheral minority, insignificant and downtrodden are coined by the power holders. Ultimately, the dominion rules the world as its own. This constructed ideology 
becomes the universal definition. Thus, the outsiders like Immigrants, Dalits and Africans are come under the lines of marginal. These discriminations are the chief factors for bringing up the psychological distress among them. According to the western people, all non-westerners are marginal. It is followed:

Ritwik feels ashamed of these politics behind the ideology. The narrator describes as follows "He feels a sudden rush of irritation for this business of other cultures, other countries, renaming and re-categorizing things, using their yardsticks, for the people, as if their definitions were universal. (177)

Being a human, everyone has a desire to live the life as he or she wants. Ritwik is one among them who wants to escape from the problematic life. He wants to walk out from the imprisoned life and decides not to return. He knows that he is not only going to abroad for his studies, but he leaves permanently to his native country. He wants to become an unknown in new land for better life than before. "At least he started from a kind of beginning: when Gavin asked him what exactly he was escaping from, he said poverty, but what he should have said was the possibility of never escaping" (186). Moreover, he never wants to live like his father who was helpless and subjugated by the employers in India. In case, Ritwik returns to India he would definitely suck by the employers. Hence, he finds that the scholarship is the route for initiating the new life in new zone. But paradoxically, he encounters the racial distinction as well as the psychological pain. Wherever he goes his past persistently infects his mind. As a result, he chooses the life of an existentialist who is free from his responsibilities. Mukherjee has made the character Ritwik as a revolutionary one. Ritwik represents as a male Moll Flanders and Roxana in this novel. They are the characters in Daniel Defoe's novels. Defoe pictures their choice of life. These characters are found happiness by becoming a prostitute. Likewise Ritwik finds the pleasure of becoming a homosexual in England. 
The country like India, homosexuality and a gay life will not be attributed by anyone. It is against the Indian ethics. Indian nation values the traditional customs, and all laws. They are valued the human beings, who are next to god. Though the ethics are constructed by men, it prevents a man from his all evil characters. In 2018, the Supreme Court of India has declared that the homosexuality is not to be considered as illegal or a criminal offence in India. Yet, the aristocratic families who value the Indian customs are resisted these kind of laws. Mostly, In India, the ethics are kept a man from his wicked and sinful persona. But in England, the scenario is different. One can be free; no one can question these things because they won't value the cultures as the Indian people do. They won't build any ethics which would resist them from all moral assets.

Ritwik loves himself. He is a young man who prices his immense desires. So, he does with strangers for the sake of his necessity. He violates all ethics, though he was born and brought out from Indian province. Ritwik represents the character of Meursault in Albert Camus' The Stranger. Meursault is a protagonist and an existentialist who is constantly pursuing women for the sake of his sexual pleasure. Though a woman offers her love to him, he ignores. Meursault wants to live as he likes and he never bothers about the consequences. Likewise, Ritwik is utterly established a gay life with various strangers in London. Matthew and zafar are one of them. They get married formerly, despite they are much attracted by the masculine partners. The characters like Matthew and Zafa are not fulfilled their sexual needs with their female partners.

On the other hand, Ritwik's brother Aritra has come to Delhi for pursuing his M.A. Degree. He too escapes from Calcutta for pursuing a better life. They have the unity that both brothers are free from the burden of responsibilities. In India, the typical parents are merely a silence of martyrdom. They sacrifice their happiness for the sake of their children. They value 
their responsibility. Unlike Indian parents, these brothers are solid swingers. They are free from all the customs and restrictions. It follows as such,

In its place was a freedom so vast and so dark it was as if they had been catapulted into deep space. No one to look after in their old age, no responsibilities, no waking up in the middle of the night worrying about the ill health of frail parents or the money to pay for their proliferating illness no rope at their neck; their lives were their own at last, no one could lay any claim on them. (188)

The immigrants' lives are strikingly questioned if their visa or permit expires unexpectedly. They cannot return to their native land. If they do, they will not get the sufficient amount in their native land to survive. So, they remain as immigrants in the alien land and do illegal jobs. It employs their work would be lasting more than twelve or thirteen hours per day. According to Ritwik, there are a lot of reasons for remaining in England when his permit expires. He decides not to return back to India because of its extreme hot weather. Secondly, he does not want to involve the life style of Indians. Ritwik gets a job as a fruit picker in London. He works with the illegal immigrants who have their personal reasons for not going back to their native place. Ritwik represents as a virtual prisoner in a new land. Gradually, he becomes a shadow behind the network of underground immigrants. He becomes a creature with no past and future. But he is imprisoned forever with infinite freedom.

The hardship of immigrants in the outside world generates the writers to focus on such topics. Cultural dilemmas are the key factors for the current Indian writers. They bring out the actual facts of the world politics. Trauma is one of the predominant themes in the contemporary conception that evokes the revolutionary changes in the protagonist mind through theoretical and marginal discourses. The ambiguity of cultural alienation approaches the new established politics in the present world. It is not a single discipline; it is a collective 
form of diversity. All non-western cultures are seen as 'other' in the context of west. The immigrants are often personified as other in front of the westerners. The other country natives are idealised by the western fantasy. Ritwik is one among them. The characters like Ritwik and others deny their cultural ethics. Thus, the imitation of non-western ends with tragic failure. Neel Mukherjee sheds light on these issues in this acclaimed novel.

\section{Works Cited}

Mukherjee, Neel. A Life Apart. India: Random House, Press, 2008.

Heidarizadeh, Negin. The Significant Role of Trauma in Literature and Psychoanalysis. Iran: Elsevier Ltd, 2015.

http://core.ac.uk

http://artoffiction.blogspot.com 